Int. J. Electrochem. Sci., 15 (2020) 8253 - 8264

International Journal of

ELECTROCHEMICAL

SCIENCE

$\underline{\text { WWW.electrochemsci.org }}$

\title{
Malathion Removal through Peroxi-Electrocoagulation and Photocatalytic Treatments. Optimization by Statistical Analysis
}

\author{
Jesús Gabriel Rangel-Peraza ${ }^{1}$, Manuel Antonio Reyes Prado ${ }^{1}$, Leonel Ernesto Amabilis-Sosa ${ }^{2}$, \\ Yaneth A. Bustos-Terrones ${ }^{2}$, Blenda Ramírez-Pereda ${ }^{2, *}$ \\ ${ }^{1}$ Tecnológico Nacional de México-División de Estudios de Posgrado e Investigación. Instituto \\ Tecnológico de Culiacán. Juan de Dios Batiz 310. Col. Guadalupe, Postal Code 80220. Culiacán, \\ Sinaloa, México. \\ ${ }^{2}$ CONACYT-División de Estudios de Posgrado e Investigación. Instituto Tecnológico de Culiacán. \\ Juan de Dios Bátiz 310. Col. Guadalupe, Postal Code 80220. Culiacán, Sinaloa, México. \\ "E-mail: blenda.ramirez@itculiacan.edu.mx
}

doi: $10.20964 / 2020.08 .08$

Received: 30 August 2019 / Accepted: 17 January 2020 / Published: 10 July 2020

The use of Malathion as an insecticide is widespread in Mexico for pests control in agriculture. Malathion biodegradation is not possible due to its high toxicity. In the present work the Malathion degradation by an Electrocoagulation process was investigated. Studies were conducted to evaluate the efficiency of pesticide removal in the presence of $\mathrm{H}_{2} \mathrm{O}_{2}$ and $\mathrm{ZnO}$. A Latin-square design was used to investigate the contribution of independent variables as applied voltage, electrode material and type of treatment applied on Malathion concentration, removal time and kinetic rate constant. Results demonstrated that the pollutant degradation follows a pseudo-first order kinetic with a maximum value of $0.0171 \mathrm{~min}^{-1}$. ANOVA tests showed that the presence of $\mathrm{H}_{2} \mathrm{O}_{2}$ and $\mathrm{ZnO}$ improve the removal of Malathion. On the other hand, all the independent variables had a significant influence on the rate of the oxidation process. During optimization process was found that the electrocoagulation with aluminum electrodes in a range of 20-30 V with the addition of $\mathrm{H}_{2} \mathrm{O}_{2}$ the kinetic removal rate increases to 0.0447 $\min ^{-1}$.

Keywords: Electrochemical process, Degradation kinetics, Malathion, Latin-square design, Statistical analysis

\section{$\underline{\text { FULL TEXT }}$}

(C) 2020 The Authors. Published by ESG (www.electrochemsci.org). This article is an open access article distributed under the terms and conditions of the Creative Commons Attribution license (http://creativecommons.org/licenses/by/4.0/). 